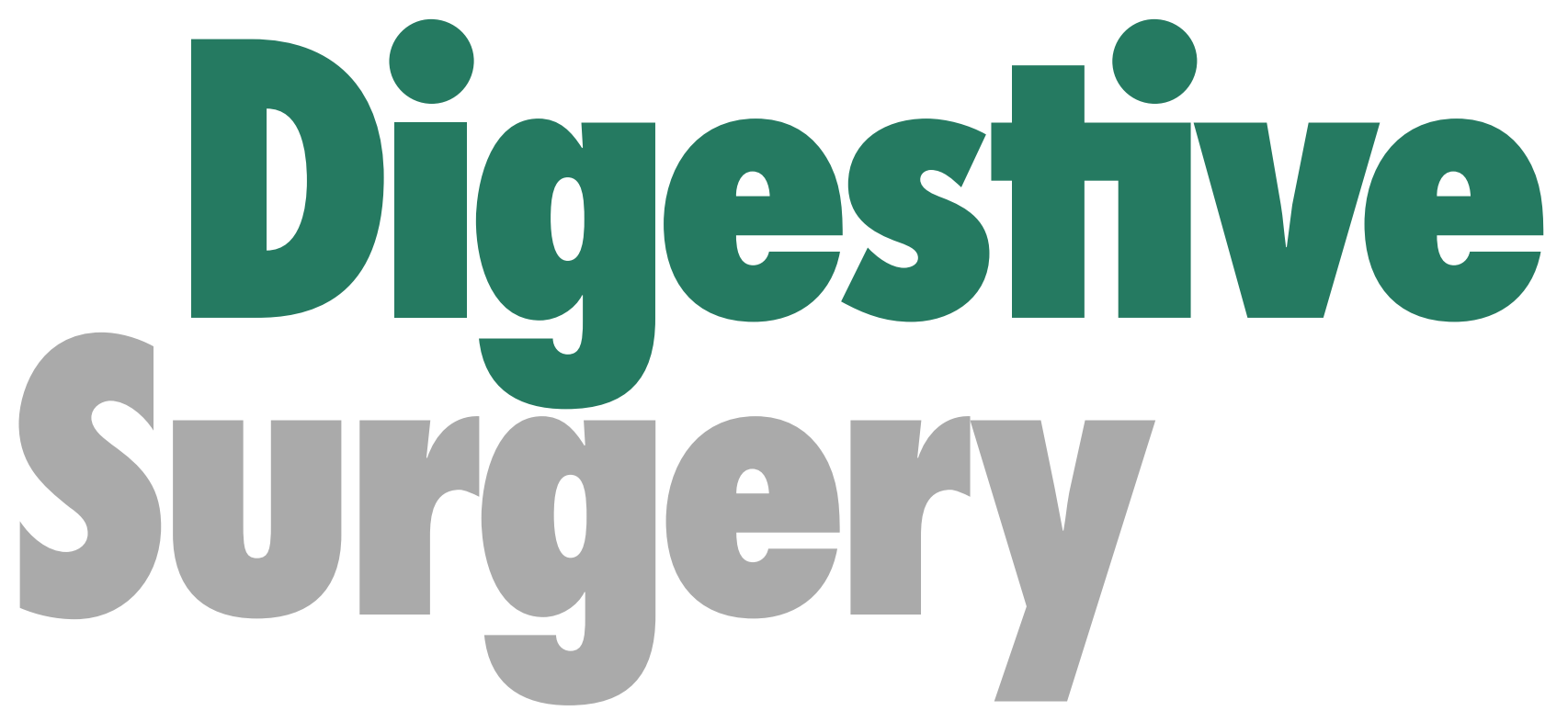

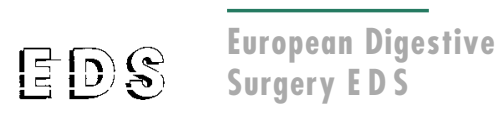

Dutch Society of
Gastro-Intestinal
Surgery N V GIC

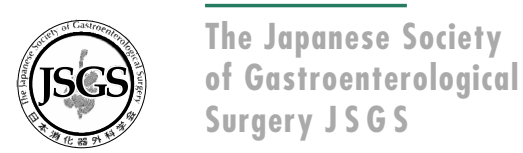




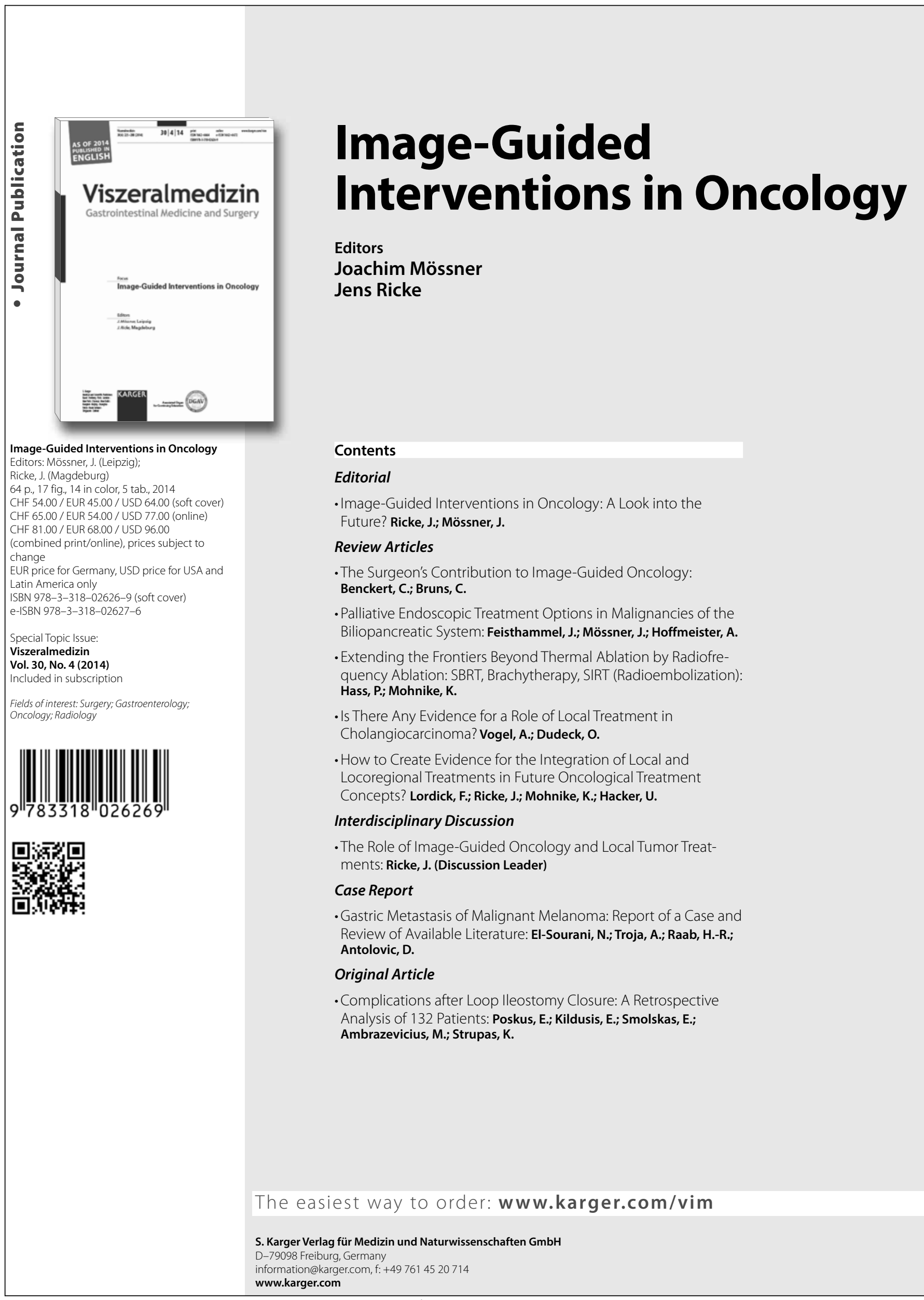




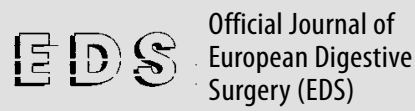

\section{EDS Editorial Representative}

C. Bassi, Verona

Official Journal of the Dutch Society of Gastro-Intestinal Surgery (NVGIC)

\section{NVGIC Editorial Representative}

R. van Hillegersberg Utrecht

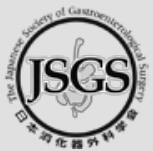

Official International Journal of the Japanese Society of Gastroenterological Surgery (JSGS)

\section{JSGS Editorial Representative}

M. Mori, Osaka

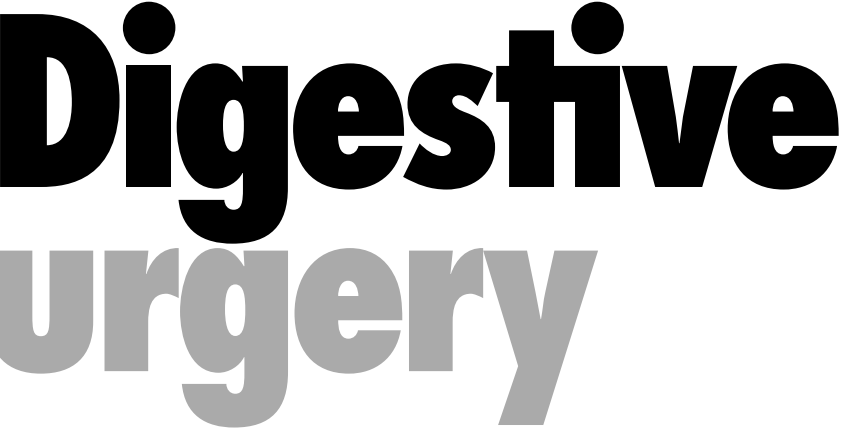

\section{An International Journal for Gastrointestinal Surgeons}

Founded 1984 by E.H. Farthmann (1984-2001) and L.F. Hollender (1984-1991) Former Editors: L.C. Carey (1986-1987) and F.G. Moody (1986-1991); M.W. Büchler (1992-2010) and J.P. Neoptolemos (2002-2010) ; H.W. Tilanus and B.P.L. Wijnhoven (2011-2013)

\section{Editor-in-Chief}

\section{K.C.P. Conlon, Dublin}

\section{Consultant Editors}

D.J. Gouma, Amsterdam

J.J.B. van Lanschot, Rotterdam

\section{Associate Editors}

M. Adham, Lyon

N. Ando, Ichikawa

J.C. Coffey, Limerick

B. Gloor, Berne

Y. Kodera, Nagoya

J.R.T. Monson, Rochester, N.Y.

S. Natsugoe, Kagoshima

D. O'Toole, Dublin

R. Parks, Edinburgh

X. Rogiers, Gent

L. Stassen, Maastricht

C. Verhoef, Rotterdam

D.C. Winter, Dublin

\section{Editorial Board}
E. Angst, Berne
G. Barauskas, Kaunas
C. Bassi, Verona
E.J.T. Belt, Rotterdam
T. Beppu, Kumamoto
S. Biondo, Barcelona
M. Bockhorn, Hamburg
R. Carter, Glasgow

P.A. Clavien, Zurich

M. d'Angelica, New York, N.Y. C.P. Delaney, Cleveland, Ohio

C. Dervenis, Athens

A. d'Hoore, Leuven

C.L. Donohoe, Dublin

M. Duxbury, Edinburgh

H. Eguchi, Osaka

H. Friess, Munich

T. Furuhata, Sapporo

L. Grande, Barcelona

M. Griffin, New Castle

R.H. Hardwick, Cambridge

S. Heinrich, Mainz

T. Keck, Lübeck

B. Knowles, Fitzroy, Vic.

S. Kobayashi, Osaka

L. Krähenbühl, Berne

C. Kunisaki, Yokohama

A.M. Lacy, Barcelona

K. Lassen, Tromsø

M.P.N. Lewis, Norwich

B. Mason, London

U. Neumann, Aachen

M. Olaussen, Goteburg

P. Pattyn, Gent

J. Rothbarth, Rotterdam

P.M. Schneider, Zurich

H. Shimada, Tokyo

S.V. Shrikhande, Mumbai

H.W. Tilanus, Rotterdam

H. Ueno, Saitama

T.M. van Gulik, Amsterdam

R. van Hillegersberg, Utrecht B.P.L. Wijnhoven, Rotterdam J.A. Windsor, Grafton

G. Zaninotto, Venezia 


\section{Digestive surgery}

\section{Submission}

Manuscripts written in English are considered and should be submitted online at

\section{www.karger.com/dsu}

Should you experience problems with your submission, please contact

\section{dsu@karger.com}

\section{Conditions}

All manuscripts are subject to editorial review. Manuscripts are received with the explicit understanding that they are not under simultaneous consideration by any other publication. Submission of an article for publication implies transfer of the copyright from the author to the publisher upon acceptance. Accepted papers become the permanent property of Digestive Surgery and may not be reproduced by any means, in whole or in part, without the written consent of the publisher. The form 'Submission Essentials' must be submitted along with the manuscript. It is available at www. kargercom/dsu_submission essentials.

\section{Types of Articles}

It is the author's responsibility to obtain permission to reproduce illustrations, table, etc. from other publications. The journal consists of the following sections:

1. Editorials - 1,000 words (max. 10 refs)

2. Review Articles - 4,000 words (max. 150 refs)

3. Original Papers $-2,700$ words

4. How I Do It $-2,000$ words

5. Historical Reviews $-2,000$ words

6. Announcements

The Case Reports Clinical Images and Short Reports sections have been discontinued

Review Articles in which a specific field is reviewed through an exhaustive literature survey. An Abstract is required and should be divided into Background, Summary and Key Messages. Review Articles should consist of a maximum of 4,000 words.

How I Do It

Digestive Surgery is publishing articles which describe modern operative techniques in the field of Gastrointestinal Surgery. The manuscript should be short and precise (maximum 10 typewritten double-spaced pages) and should contain 1-4 videos (max. $250 \mathrm{Mb}$ ) to explain the surgical procedure. Decisions of submitted papers within 6 weeks: A decision will be reached within 6 weeks for manuscripts submitted to the 'How I Do It' section.

\section{Conflicts of Interest}

Authors are required to disclose any sponsorship or funding arrangements relating to their research and all authors should disclose any possible conflicts of interest. Conflict of interest statements will be published at the end of the article.

Ethics

Published research must comply with the guidelines for human studies and animal welfare regulations. Authors should state that subjects have given their informed consent and that the study protocol has been approved by the institute's committee on human research. Further, they should also state that animal experiments conform to in stitutional standards.

\section{Statistics}

Authors must conform to these guidelines or any work sub mitted to Digestive Surgery will be returned without review. The advice of a statistician is required for any analysis beyond simple data description or comparisons and must be mentioned in the 'Methods'. All data should be described non-parametrically: median, interquartile range, $95 \% \mathrm{CI}$, range. The use of parametric descriptors including mean, SEM and SD must not be used unless clearly justified in the 'Methods'. Analysis of simple comparisons should also be undertaken using non-parametric methods, including the $\chi^{2}$, Fisher's Exact Probability and Spearman's Rank Correlation tests for categorical data and the Rank-Sum and
Mann-Whitney U tests for continuous data. All analyses should be two-sided 'p' unless justified in the 'Methods'.

\section{Arrangement}

Title page: The first page of each paper should indicate the title, the authors' names (max number of authors: 6), the institute where the work was conducted, and a short title for use as running head.

Full address: The exact postal address of the corresponding author complete with postal code must be given at the bottom of the title page. Please also supply phone and fax numbers, as well as e-mail address.

Key words: Please supply 3-10 key words in English that reflect the content of the paper.

Abstracts of Review Articles: Should be divided into the following subsections: Background, Summary and Key Messages. The Background should provide a brief clinical context for the review and is followed by the Summary, which should include a concise description of the main topics covered in the text. The Key Messages encapsulate the main conclusions of the review.

Abstract: Each paper needs an abstract of up to 200 words. Original papers need an abstract structured as follows:

Background/Aims: What is the major problem that

prompted the study?

How was the study performed?

Results: Most important findings?

Conclusion: Most important conclusion?

Acknowledgements: Financial support for the study and any conflicts of interest must be stated in the Acknowledgements.

Footnotes: Avoid footnotes.

Abbrevations: All non-essential abbrevations should be removed and replaced by the full term.

Tables and illustrations: Tables and illustrations (both numbered in Arabic numerals) should be prepared on separate pages. Tables require a heading and figures a legend, also prepared on a separate page. For the reproduction of illustrations, good drawings and original photographs are preferred; slides may also be accepted; negatives or photocopies cannot be used. Due to technical reasons, figure with a screen background should not be submitted. When possible, group several illustrations in one block for reproduction (max size $180 \times 223 \mathrm{~mm}$ ) or provide crop marks. On the back of each illustration, indicate its number, the author's name, and 'top' with a soft pencil. Electronically submitted $\mathrm{b} / \mathrm{w}$ half-tone and color illustrations must have a final resolution of $300 \mathrm{dpi}$ after scaling, line drawings one of 800-1,200 dpi.

Percentage values: Percentage values must never be given alone. They must be accompanied by the actual numbers.

\section{Color Illustrations}

Online edition: Color illustrations are reproduced free of charge. In the print version, the illustrations are reproduced in black and white. Please avoid referring to the colors in the text and figure legends.

Print edition: Up to 6 color illustrations per page can be integrated within the text at CHF 800.00 per page.

\section{References}

In the text identify references by Arabic numerals [in square brackets]. Material submitted for publication but not yet accepted should be noted as [unpublished data] and not be included in the reference list. The list of references should include only those publications which are cited in the text. Do not alphabetize; number references in the order in which they are first mentioned in the text. The surnames of the authors followed by initials should be given. There should be no punctuation other than a comma to separate the authors. Preferably, please cite all authors. Abbreviate journal names according to the Index Medicus system. Also see International Committee of Medical Journal Editors: Uniform requirements for manuscripts submitted to biomedical journals (www.icmje.org).
Examples

(a) Papers published in periodicals: Chatel J-M, Bernard $\mathrm{H}$ Orson FM: Isolation and characterization of two complete Ara h 2 isoforms cDNA. Int Arch Allergy Immunol 2003;131:14-18.

(b) Papers published only with DOI numbers:

Theoharides TC, Boucher W, Spear K: Serum interleukin-6 reflects disease severity and osteoporosis in mastocytosis patients. Int Arch Allergy Immunol DOI: $10.1159 / 000063858$.

(c) Monographs: Matthews DE, Farewell VT: Using and Understanding Medical Statistics, ed 3, revised. Basel, Karger, 1996.

(d) Edited books: DuBois RN: Cyclooxygenase-2 and colorectal cancer; in Dannenberg AJ, Dubois RN (eds): COX-2. Prog Exp Tum Res. Basel, Karger, 2003, vol 37, pp 124-137.

Reference Management Software: Use of EndNote is recommended for easy management and formatting of citations and reference lists.

\section{Digital Object Identifier (DOI)}

S. Karger Publishers supports DOIs as unique identifier for articles. A DOI number will be printed on the title page of each article. DOIs can be useful in the future for identifying and citing articles published online without volume or issue information. More information can be found at www.doi.org.

\section{Supplementary Material}

Supplementary material is restricted to additional data that are not necessary for the scientific integrity and conclusions of the paper. Please note that all supplementary files will undergo editorial review and should be submitted together with the original manuscript. The Editors reserve the right to limit the scope and length of the supplementary material. Supplementary material must meet production quality standards for Web publication without the need for any modification or editing. In general, supplementary files should not exceed $10 \mathrm{Mb}$ in size. All figures and tables should have titles and legends and all files should be supplied separately and named clearly. Acceptable files and formats are: Word or PDF files, Excel spreadsheets (only if the data cannot be converted properly to a PDF file), and video files (.mov, .avi, .mpeg).

\section{Author's Choice $^{\mathrm{TM}}$}

With this option the author can choose to make his article freely available online against a one-time fee of CHF 3,000.00. This fee is independent of any standard charges for supplementary pages, color images etc. which may apply. More information can be found at www.karger. com/authors_choice.

\section{Page Charges}

Original Papers exceeding the first 3 printed pages which are free will cost CHF 325.00 per extra page.

\section{Electronic Proofs}

Unless indicated otherwise, proofs will be e-mailed to the corresponding author

\section{Reprints}

Order forms and a price list are sent with the proofs. Orders submitted after the issue is printed are subject to considerably higher prices.

\section{KARGER}

E-Mail karger@karger.com www.karger.com
(C) 2014 S. Karger AG, Basel 


\section{Digestive surgery}

ISSN Print Edition: 0253-4886 ISSN Online Edition: 1421-9883

Journal Homepage: www.karger.com/dsu

Publication Data: Digestive Surgery is published 6 times a year. Volume 31 with 6 issues appears in 2014 .

Copyright: (c) 2014 S. Karger AG, Basel (Switzerland). All rights reserved. No part of this publication may be translated into other languages, reproduced or utilized in any form or by any means, electronic or mechanical, including photocopying, recording, microcopying, or by any information storage and retrieval system, without permission in writing from the publisher or, in the case of photocopying, direct payment of a specified fee to the Copyright Clearance Center.

Disclaimer: The statements, opinions and data contained in this publication are solely those of the individual authors and contributors and not of the publisher and the editor(s). The appearance of advertisements in the journal is not a warranty, endorsement, or approval of the products or services advertised or of their effectiveness, quality or safety. The publisher and the editor(s) disclaim responsibility for any injury to persons or property resulting from any ideas, methods, instructions or products referred to in the content or advertisements.
Subscription Rates: Subscriptions run for a full calendar year. Prices are given per year. Personal subscription:

Print or Online

CHF 381.00

EUR 312.00

Print+Online combined CHF 429.00

EUR 351.00

USD 381.00 USD 429.00

postage and handling (added to print and print+online)

CHF 44.40 Europe, CHF 64.80 Overseas

EUR 36.00

USD 58.80

Institutional subscription

Print or Online

Print+Online combined

CHF 2629.00 CHF 2892.00

EUR 2155.00 CHF 2892.00

USD 2629.00

USD 2892.00

postage and handling (added to print and print+online)

CHF 55.50 Europe, CHF 81.00 Overseas

EUR 45.00

USD 73.50

Discount subscription prices:

Please enquire about reduced rates for members of affiliated societies.
Back Volumes and Single Issues: Information on availability and prices of single print issues and print or electronic back volumes can be obtained from Customer Service at service@karger.ch.

Bibliographic Indices: This journal is regularly listed in bibliographic services, including Current Contents ${ }^{\circledR}$ and PubMed/MEDLINE.

Photocopying: This journal has been registered with the Copyright Clearance Center (CCC), as indicated by the code appearing on the first page of each article. For readers in the US, this code signals consent for copying of articles for personal or internal use, or for the personal or internal use of specific clients, provided that the stated fee is paid per copy directly to

Copyright Clearance Center Inc.

222 Rosewood Drive

Danvers, MA 01923 (USA)

A copy of the first page of the article must accompany payment. Consent does not extend to copying for general distribution, for promotion, for creating new works, or for resale. In these cases, specific written permission must be obtained from the copyright owner,

S. Karger AG, P.O. Box

CH-4009 Basel (Switzerland).
Subscription Orders:

Orders can be placed at agencies, bookstores, directly with the Publisher

\section{S. Karger AG}

Medical and Scientific Publishers

Allschwilerstrasse 10

CH-4009 Basel

Switzerland

t: +41613061111

f: +41613061234

e: karger@karger.com

w: www.karger.com

(for courier services only:

Allschwilerstrasse 10

CH-4055 Basel) or further Karger offices

or representatives:

\section{Germany}

S. Karger GmbH

Postfach

79095 Freiburg

Deutschland

(Hausadresse: Wilhelmstrasse 20A,

79098 Freiburg

t: $\quad+49761452070$

f: +497614520714

e: information@karger.de

w: www.karger.de

\section{Japan}

Karger Japan, Inc.

Shiba Daimon Asahi Bldg. 2F

1-2-23 Shiba Daimon

Minato-ku

Tokyo 105-0012

Japan +81364356242

f: +81364356244

e: publisher@karger.jp

w: www.karger.jp
USA

S. Karger Publishers, Inc.

26 West Avon Road

P.O. Box 529

Unionville, CT 06085

USA

Toll free: +18008285479

t: +18606757834

f: +18606757302

e: karger@snet.net

France

Enter \& Read

Albertine Luginbuhl

23, rue du Départ, boite 37

75014 Paris

France

t: $+33(0) 681047685$

e: albertineluginbuhl@orange.fr

South East Asia, China and Taiwan Karger Regional Office (Malaysia)

Level 28-03-03A, PJ Exchange

No. 16A, Persiaran Barat

46050 Petaling Jaya

Selangor Darul Ehsan

Malaysia

t: +60379620158

f: +60379620001

e: service@karger.cn; r.chew@karger.cn
Karger China

51F Raffles City Centre

268 Xi Zang Middle Road

Huang Pu District

Shanghai 200001

P.R. China

t: +862123127673

f: +862123127777

e: service@karger.cn r.chew@karger.cn

w: www.karger.cn

India, Bangladesh, Sri Lanka Karger India

Plot No. 17, Yusuf Sarai Market

Plot No. 17, Yusuf Sarai Market
B.L. Glass Building, 2nd Floor

Sri Aurobindo Marg

New Delhi 110016

India

t: +911146029633

f: +91114602963

c: +919891052128

e: r.kumar@kargerindia.com

w: www.karger.com

Change of Address:

Both old and new address should be sent

to the subscription source.

\section{KARGER}

E-Mail karger@karger.com www.karger.com
(C) 2014 S. Karger AG, Basel

The Journal Home Page is available at:

www.karger.com/dsu 


\section{Gastro Update Europe 2015}

\section{$2^{\text {nd }}$ European Update Congress in Gastroenterology}

Budapest, 12-13 June 2015

- Complete medical field in two days

- Cutting-edge study results

- Ensured practical relevance

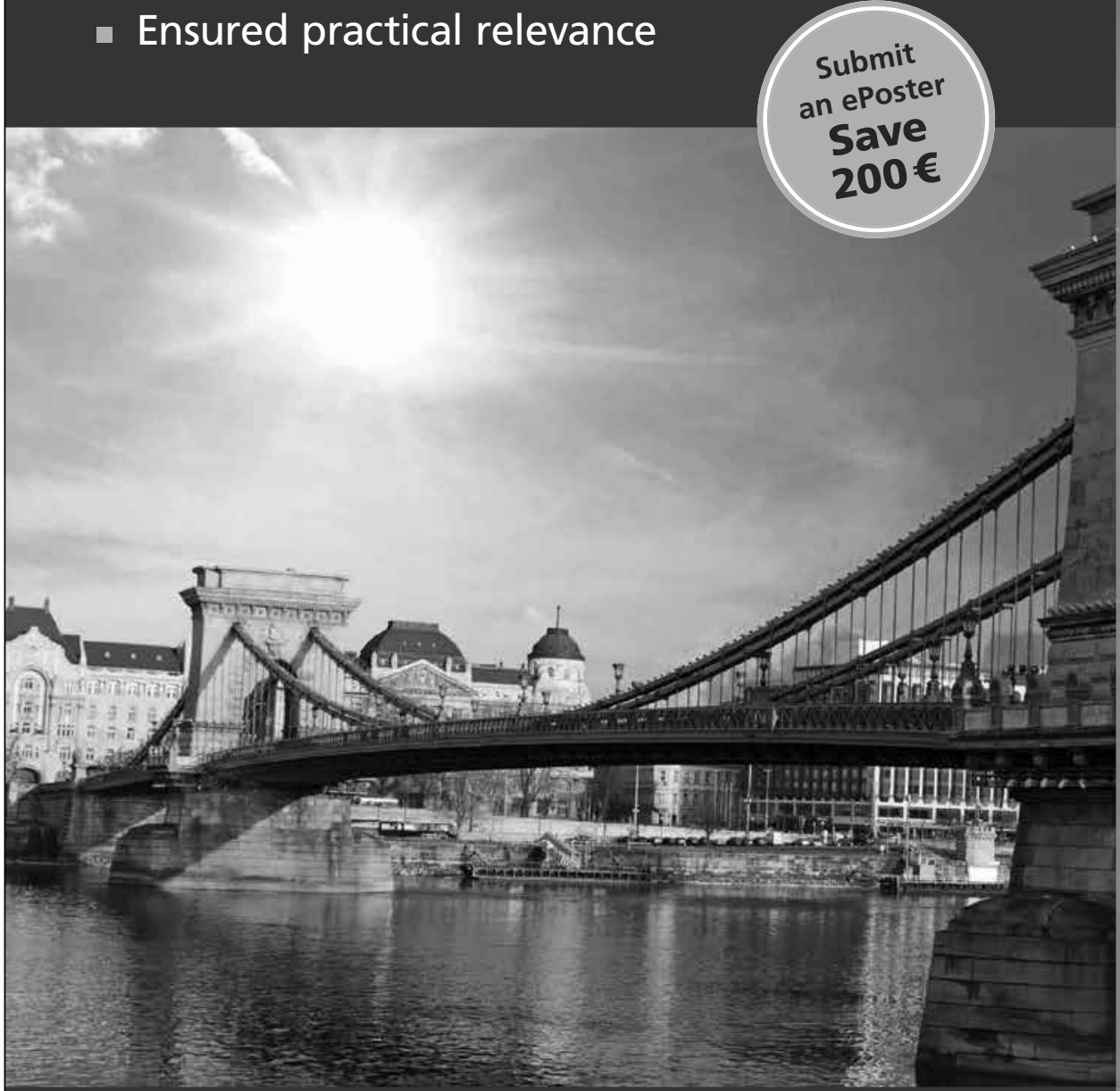

Scientific board

Peter Layer (Germany)

Lars Lundell (Sweden)

Jan Tack (Belgium)

Guido Tytgat (Netherlands)

Registration and further information www.gastro-update-europe.eu

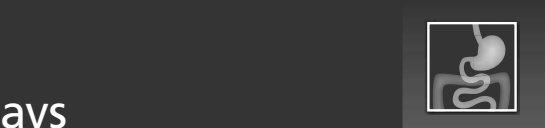

Oesophagus/Stomach/ Duodenum: Benign

Peter Malfertheiner (Germany)

Oesophagus/Stomach/

Small Bowel: Oncology

Aziz Zaanan (France)

Pancreas

Peter Layer (Germany)

Hot Topic: Intestinal

Absorption/Malabsorption

Gerhard Rogler (Switzerland)

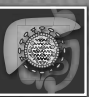

Hepatology I

Michael Trauner (Austria)

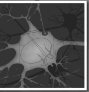

Motility and Functional

Disorders

Jan Tack (Belgium)

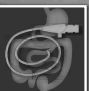

Endoscopy I

Christian Ell (Germany)

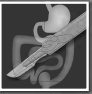

Surgery: Upper GI Tract Lars Lundell (Sweden)

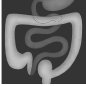

Large/Small Bowel I Peter Irving (UK)

Hot Topic: Gut Microbiota

\& Gastroenterological

Diseases

Antonio Gasbarrini (Italy)

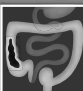

Large/Small Bowel II Jaroslaw Regula (Poland)

Endoscopy II

Alessandro Repici (Italy)

Surgery: Lower GI Tract Ronan O'Connell (Ireland)

Hepatology Frederik Nevens (Belgium) 


\section{Contents}

See the journal website for contents

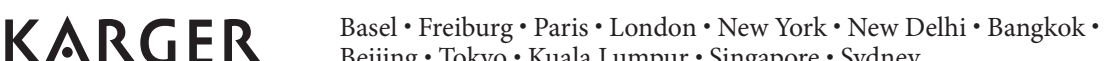
Beijing $\cdot$ Tokyo $\cdot$ Kuala Lumpur $\cdot$ Singapore $\cdot$ Sydney 


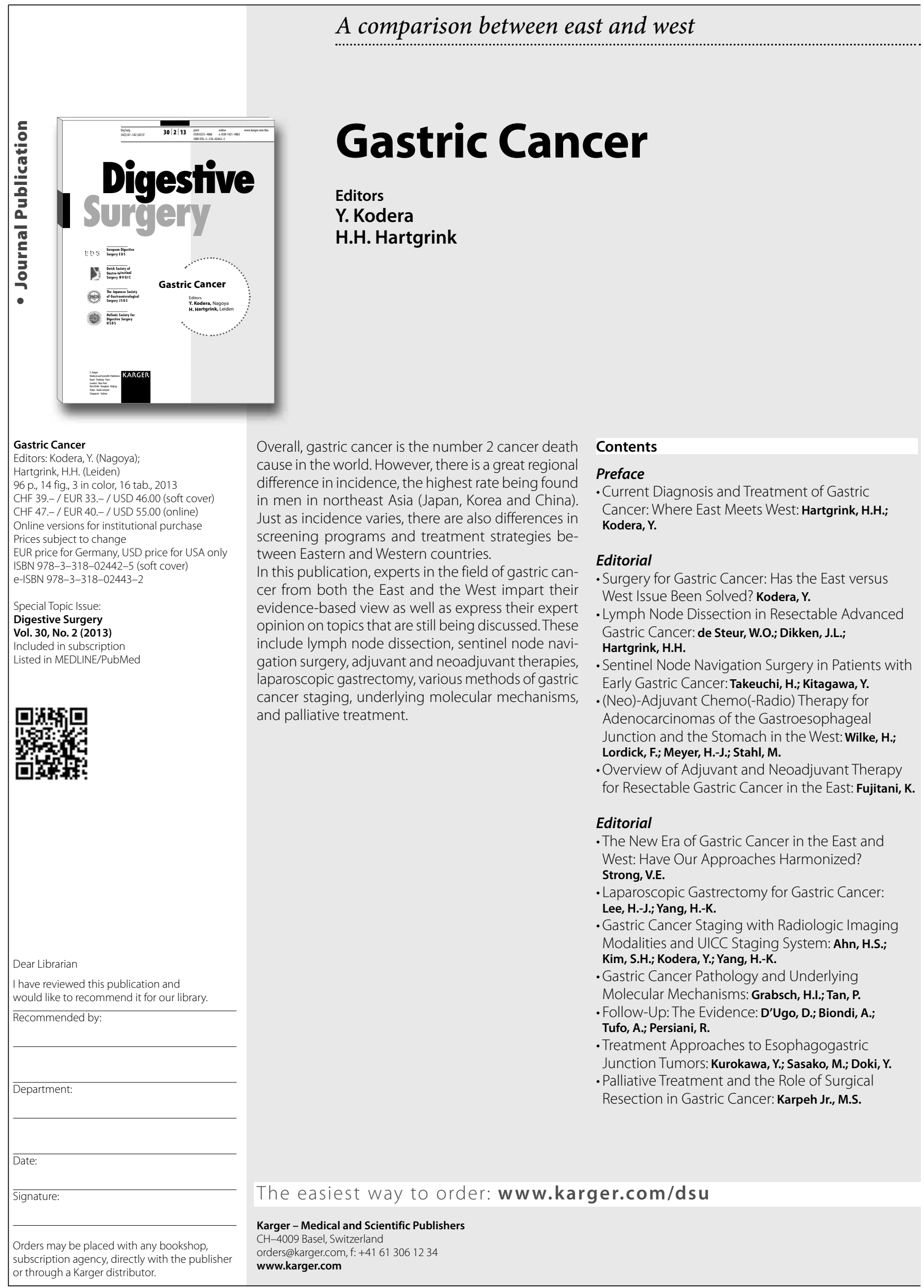




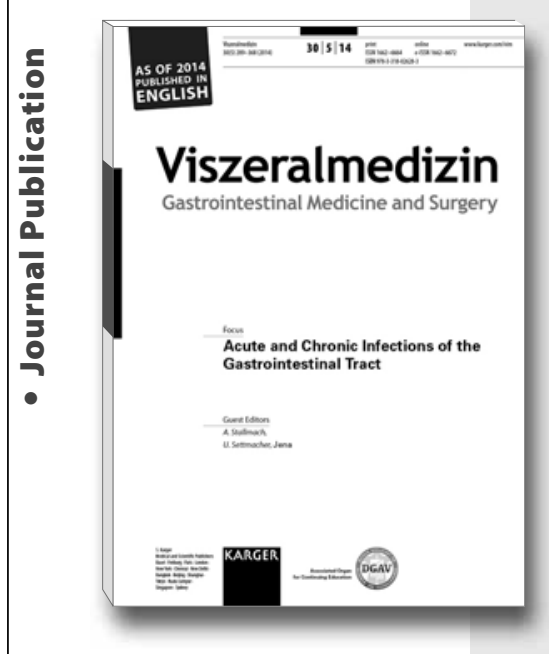

\title{
Acute and Chronic Infections of the Gastrointestinal Tract
}

\author{
Editors \\ A. Stallmach \\ U. Settmacher
}

Acute and Chronic Infections of the Gastrointestinal Tract

Editors: Stallmach, A.; Settmacher, U. (Jena) 80 p., 13 fig., 11 in color, 23 tab., 2014

CHF 62.00 / EUR 52.00 / USD 73.00 (soft cover)

CHF 74.00 / EUR 62.00 / USD 88.00 (online)

Online version for institutional purchase

prices subject to change

EUR price for Germany, USD price for USA and

Latin America only

ISBN 978-3-318-02628-3 (soft cover)

e-ISBN 978-3-318-02629-0

Special Topic Issue:

Viszeralmedizin

Vol. 30, No. 5 (2014)

Included in subscription

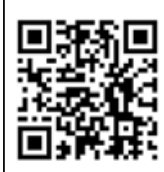

Contents

\section{Editorial}

- Acute and Chronic Infections of the Gastrointestinal Tract: Stallmach, A.; Settmacher, U.

Review Articles

- Calculated Antibiosis of Acute Cholangitis and Cholecystitis: Bornscheuer, T.; Schmiedel, S.

- Rational Therapy of Clostridium difficile Infections: Keller, P.M.; Weber, M.H.

- Perioperative Antibiotic Prophylaxis and Antimicrobial Therapy of Intra-Abdominal Infections: Hagel, S.; Scheuerlein, $\mathbf{H}$.

- Antibiosis of Necrotizing Pancreatitis: Arlt, A.; Erhart, W.;

Schafmayer, C.; Held, H.-C.; Hampe, J.

- Infections and Chronic Inflammatory Bowel Disease: Kucharzik, T.; Maaser, C.

-Therapy of Liver Abscesses: Lübbert, C.; Wiegand, J.; Karlas, T.

\section{Interdisciplinary Discussion}

- Acute and Chronic Infections of the Gastrointestinal Tract: Kujath, P. (Discussion Leader)

\section{Original Article}

- Verrucous Oesophageal Carcinoma: Single Case Report and Case Series Including 15 Patients - Issues for Consideration of Therapeutic Strategies: Behrens, A.; Stolte, M.; Pech, O.; May, A.; Ell, C.

\section{Review Article}

- Cytoreductive Surgery and HIPEC in the Baltic States:

An International Scientific Workshop with Live Surgery: Poskus, E.; Strupas, K.; Gushchin, V.; Sugarbaker, P.H. 
(Continued from back cover)

347 Molecular Markers for Recurrence and Sensitivity to Preoperative Chemoradiotherapy in Locally Advanced Rectal Tumours

Romain, B.; Meyer, N.; Brigand, C.; Chenard, M.-P.;

Schneider, A.; Guenot, D. (Strasbourg)

354 Effect of Laparoscopic Antireflux Surgery on Esophageal Motility

Fuchs, H.F.; Gutschow, C.A.; Brinkmann, S.; Herbold, T.; Bludau, M.; Schröder, W.; Bollschweiler, E.; Hölscher, A.H.; Leers, J.M. (Cologne)

359 Prevalence Analysis of de novo Hepatic Steatosis Following Pylorus-Preserving

Pancreaticoduodenectomy

Yoo, D.-G.; Jung, B.-H.; Hwang, S.; Kim, S.-C.; Kim, K.-H.; Lee, Y.-J.; Ahn, C.-S.; Moon, D.-B.; Kim, K.-M.; Ha, T.-Y.; Kang, S.-H.; Kim, N. (Seoul)

377 Reappraisal of the Inferior Right Hepatic Vein Preserving Liver Resection

Takahashi, M.; Hasegawa, K.; Aoki, T.; Seyama, Y.; Makuuchi, M.; Kokudo, N. (Tokyo)
How I Do It

249 Pancreaticoduodenectomy with Harmonic Focus ${ }^{\circledR}$ Curved Shears for Cancer

Salvia, R.; Malleo, G.; Marchegiani, G.; Butturini, G.; Esposito, A.; Bassi, C. (Verona)

324 Efficient and Safe Small-Bowel Adhesiolysis Klasen, J.; Wenning, A.; Storni, F. (Bern); Angst, E. (Schaffhausen); Gloor, B. (Bern)

400 EDS Society News

401 HBPD Table of Contents Vol. 13, No. 5, 2014

404 HBPD Table of Contents Vol. 13, No. 6, 2014 


\section{Review Articles}

255 New Perspectives in the Assessment of Future Remnant Liver

Cieslak, K.P.; Runge, J.H.; Heger, M.; Stoker, J.; Bennink, R.J.; van Gulik, T.M. (Amsterdam)

366 Parastomal Hernia: A Growing Problem with New Solutions

Aquina, C.T.; Iannuzzi, J.C.; Probst, C.P.; Kelly, K.N.; Noyes, K.; Fleming, F.J.; Monson, J.R.T. (Rochester, N.Y.)

384 Single Incision versus Conventional Multiport Laparoscopic Appendectomy: A Systematic Review and Meta-Analysis of Randomized Controlled Trials Zhou, H.; Jin, K.; Zhang, J.; Wang, W.; Sun, Y.; Ruan, C.; Hu, Z. (Shanghai)

392 Fast-Track Programs Versus Traditional Care in Hepatectomy: A Meta-Analysis of Randomized Controlled Trials

Lei, Q.; Wang, X.; Tan, S.; Xia, X. (Nanjing); Zheng, H. (Dongguan); Wu, C. (Nanjing)

Original Papers

269 Validation of the Estimation of Physiologic Ability and Surgical Stress (E-PASS) Score for Maintenance Hemodialysis Patients Undergoing Elective Abdominal Surgery

Abe, H.; Mafune, K.; Minamimura, K.; Hirata, T. (Tokyo)

276 Minimal versus Definitive Surgery in Managing Peptic Ulcer Bleeding: A Population-Based Cohort Study

Sverdén, E.; Sondén, A.; Leinsköld, T. (Stockholm); Lagergren, J. (Stockholm/London); Lu, Y. (Stockholm)

283 Evaluation of Esophagogastric Varices after Adult-toAdult Living Donor Liver Transplantation Using a Left Lobe Graft

Ishizaki, Y.; Konishi, N.; Yoshimoto, J.; Sugo, H.; Imamura, H.; Kawasaki, S. (Tokyo)
291 Laparoscopic Lysis of the Ligament of Treitz for Superior Mesenteric Artery Syndrome

Fang, J.; Wei, B.; Zheng, Z.; Lei, P.; Chen, T.; Wei, H. (Guangzhou)

297 Endoscopic Ultrasonography for Tumor Node Staging and Vascular Invasion in Pancreatic Cancer: A Meta-Analysis

Li, J.; He, R.; Li, Y.; Cao, G.; Ma, Q.; Yang, W. (Xi'an)

306 Effectiveness of Sternocleidomastoid Flap Repair for Cervical Anastomotic Leakage after Esophageal Reconstruction

Nakajima, M.; Satomura, H.; Takahashi, M.; Muroi, H. (Mibu); Kuwano, H. (Maebashi); Kato, H. (Mibu)

312 Metzenbaum-Assisted Liver Resection: A Safe and Effective Liver Resection Technique

Schwartz, M.E. (New York, N.Y.); Miller, C.M. (Cleveland, Ohio); Roayaie, S. (New York, N.Y.); Gomatos, I.P. (Athens); Konstadoulakis, M.M. (New York, N.Y.)

318 The Clinical Indication and Feasibility of the Enhanced Recovery Protocol for Curative Gastric Cancer Surgery: Analysis of 147 Consecutive Experiences Lee, J.; Jeon, H. (Seoul)

327 Differential Impact of the Neutrophil-Lymphocyte Ratio on the Survival of Patients with Stage IV Gastric Cancer Tanaka, H.; Muguruma, K.; Toyokawa, T.; Kubo, N.; Ohira, M.; Hirakawa, K. (Osaka)

334 Quality of Life in Peritoneal Carcinomatosis: A Prospective Study in Patients Undergoing Cytoreductive Surgery and Hyperthermic Intraperitoneal Chemotherapy (HIPEC)

Albertsmeier, M.; Hauer, A.; Niess, H.; Werner, J. (Munich); Graeb, C. (Hof); Angele, M.K. (Munich)

341 Long-Term Effectiveness of Preserved Celiac Branch of Vagal Nerve After Roux-en-Y Reconstruction in Laparoscopy-Assisted Distal Gastrectomy Inokuchi, M.; Sugita, H.; Otsuki, S.; Sato, Y.; Nakagawa, M.; Kojima, K. (Tokyo) 